\section{IS IT POSSIBLE TO EXPAND A PORCELAIN RING WITHOUT BREAKING? \\ To the Editor:}

We read the article by Wilbring and colleagues $^{1}$ with great interest. We appreciate the authors for their great efforts to reveal new approaches for the treatment of mitral valve disease. The concepts of the valve-in-valve and valve-in-ring procedures were described well. We think there is no need to discuss these approaches. However, analyzing the concept and discussing the valve-in-native-ring procedure will further expand our horizon on the treatment of calcified mitral valve disease.

Catheter-based valve-replacement procedures definitely require a durable landing zone for the cage that carries the bioprosthetic tissue of the valved prosthesis. Otherwise, the cage cannot be anchored to the annular level while expanding the valved prosthesis with balloon dilatation. From this perspective, implantation of the valved bioprosthesis within the severely calcified mitral annulus may sound somewhat logical at first glance. However, when assessing the suitability of a new method or technique to be applied, in addition to the surgical ones, physical factors affecting the procedure should be judged in a rigorous manner in preoperative planning. In other words, before performing a new method or technique, confirmation of technical suitability of the proposed method must be based on the classic

\footnotetext{
The Editor welcomes submissions for possible publication in the Letters to the Editor section that consist of commentary on an article published in the Journa or other relevant issues. Authors should: - Include no more than 500 words of text, three authors, and five references. - Type with double-spacing - See http://jtcs.ctsnetjournals.org/misc/ifora.shtm for detailed submission instructions. - Submit the letter electronically via jtcvs.editorialmanager.com. Letters commenting on an article published in the JTCVS will be considered if they are received within 6 weeks of the time the article was published. Authors of the article being commented on will be given an opportunity of offer a timely response ( 2 weeks) to the letter. Authors of letters will be notified that the letter has been received. Unpublished letters cannot be returned.
}

teachings in the literature. The severely calcified mitral annulus can be determined preoperatively in the echocardiographic examination. In this way, intraoperative determination of a severely calcified mitral annulus would not be a surprise for surgeons. Otherwise, the technical suitability of a novel procedure, not based on the classic teachings in the literature, could have been confirmed with simulated animal studies before applying it in patients. For example, a novel leaflet plication clip for the repair of the posterior mitral valve prolapsed was tested by Feins and colleagues ${ }^{2}$ in an animal model.

The second point is that the mitral valve apparatus does not have a whole anatomic annulus. It is actually a discontinuous band of connective tissue that exists only in some parts of the attachment of posterior leaflet. ${ }^{3,4}$ Therefore, even if the mitral annulus was severely calcified, settling the valved bioprosthesis within such a severely calcified mitral annulus by expanding its cage may not result in long-lasting anchoring of the bioprosthesis. This result, including valve dislocation and paravalvular leakage, was observed by the authors on the first postoperative day. ${ }^{1}$ In contrast, better outcomes would have been obtained if the valve-replacement technique in a severely calcified mitral annulus had been applied as presented by Mihaljevic and colleagues.

It can be speculated that the authors' approach for severely calcified annulus ${ }^{1}$ resembles the attempt performed for expanding a porcelain ring. Therefore, a novel procedure with unpredictable results should not be preferred instead of the valvereplacement procedure. Nonetheless, despite all the criticism, the innovative approach described by the authors should be appreciated.

Murat Tavlasoglu, $M D^{a}$ Adem Guler, $M D^{b}$

Mustafa Kurkluoglu, $M D^{c}$

${ }^{a}$ Department of Cardiovascular Surgery
Diyarbakir Military Medical Hospital Diyarbakir, Turkey

${ }^{b}$ Department of Cardiovascular Surgery

Gulhane Military Medical Academy Ankara, Turkey

${ }^{c}$ Department of Cardiovascular Surgery

Children's National Heart Institute Children's National Medical Center Washington, DC

\section{References}

1. Wilbring M, Alexiou K, Tugtekin SM, Arzt S, Ibrahim K, Matschke K, et al. Pushing the limits-further evolutions of transcatheter valve procedures in the mitral position, including valvein-valve, valve-in-ring, and valve-in-native-ring. J Thorac Cardiovasc Surg. 2014;147:210-9.

2. Feins EN, Yamauchi H, Marx GR, Freudenthal FP, Liu H, Del Nido PJ, et al. Repair of posterior mitral valve prolapse with a novel leaflet plication clip in an animal model. J Thorac Cardiovasc Surg. 2014; 147:783-91.

3. Timek TA, Miller DC. Experimental and clinical assessment of mitral annular area and dynamics: what are we actually measuring? Ann Thorac Surg. 2001;72:966-74.

4. Carpentier A, Adams DH, Filsoufi F. Surgical anatomy and physiology. In: Carpentier A, Adams DH, Filsoufi F, eds. Carpentier's reconstructive valve surgery. Philadelphia, PA: Saunders, Elsevier; 2010:28. 5. Mihaljevic T, Koprivanac M, Kelava M, Smedira NG, Lytle BW, Blackstone EH. Mitral valve replacement in patients with severely calcified mitral valve annulus: surgical technique. J Thorac Cardiovasc Surg. 2013;146:233-5

http://dx.doi.org/10.1016/ j.jtcvs.2014.01.039

\section{Reply to the Editor:}

We appreciate the constructive comments of Tavlasoglu and colleagues on our recently published case series. ${ }^{1}$ We are pleased that they read our article carefully, intensively engaging themselves with the reported innovative techniques.

Tavlasoglu and colleagues seem mainly in agreement with our reported valve-in-valve and valve-inring approaches. Apart from this, they mentioned some concern about the valve-in-native-ring procedure and added some important points to this ongoing discussion.

We absolutely agree that new methods need advance confirmation of technical suitability according to 
actual ethical standard procedures to meet corresponding concerns.

Tavlasoglu and colleagues particularly pointed out in the valve-innative-ring case that preoperative echocardiography should have determined the severe calcification and thus allowed optimized surgical planning to include the valve replacement technique in a severely calcified mitral annulus, as previously presented by Mihaljevic and associates. ${ }^{2}$ In this particular case, we must recognize that the preoperative findings concerning mitral annular calcifications were obviously underestimated, resulting in the attempt at conventional mitral repair. At any rate, this apparent misinterpretation cannot be argued and thus was intentionally not included in our recently published series. ${ }^{1}$ Despite extraordinary diligence, however, real life sometimes includes painful twists of fate. The pivotal point was when our operating surgeon came into this futile situation and a bail-out plan was needed. Too much crossclamp time had been spent to allow further extension, and death on the operating table was no option. For those reasons we performed as an absolute bail-out procedure the direct-view implantation of the transcatheter valve. ${ }^{1}$ As Tavlasoglu and colleagues correctly remarked, this resulted in progressive paravalvular leakage and the beginning of valve dislocation on the first postoperative day. Only after secondlook surgery, including refixation of the transcatheter valve with a single running suture to an atrial cuff, was a stable valvular function achieved.

We absolutely agree with the concerns stated by Tavlasoglu and colleagues. For those reasons, we have already pointed out that "this case demonstrated that "valve-in-native ring' procedures are not really feasible" and this bail-out procedure potentially only "worked once, but can surely not be recommended at all." We summarized that "with the present available devices, 'valve-in-native-ring' seems not to be... possible." "With regard to ongoing developments, valve-in-nativering could become feasible in the future, but at the present, it is surely not. ${ }^{3}$

From our point of view, conventional surgery unarguably remains the standard treatment for nearly any mitral valve disease. Nonetheless, we believe, that valve-in-valve and valve-in-ring procedures in the mitral position have a particular value in selected cases. In this spirit, we like to cite Michael Mack's sophisticated commentary on valve-in-valve procedures: "The procedure is extremely promising, but as with any new technology or technique, embrace should be cautious until the limitations have been well defined and addressed." 4

Manuel Wilbring, MD Sems-Malte Tugtekin, MD Utz, Kappert, MD Department of Cardiac Surgery University Heart Center Dresden Dresden, Germany

\section{References}

1. Wilbring M, Alexiou K, Tugtekin SM, Arzt S, Ibrahim K, Matschke K, et al. Pushing the limits-further evolutions of transcatheter valve procedures in the mitral position, including valvein-valve, valve-in-ring, and valve-in-native-ring. J Thorac Cardiovasc Surg. 2014;147:210-9.

2. Mihaljevic T, Koprivanac M, Kelava M, Smedira NG, Lytle BW, Blackstone EH. Mitral valve replacement in patients with severely calcified mitral valve annulus: surgical technique. J Thorac Cardiovasc Surg. 2013;146:233-5.

3. Lutter G, Pokorny S, Frank D, Cremer J, Lozonschi L. Transapical mitral valve implantation: the Lutter valve. Heart Lung Vessel. 2013;5:201-6.

4. Mack M. Invited commentary. Ann Thorac Surg 2013;95:117-8

http://dx.doi.org/10.1016/ j.jtcvs.2014.02.058

\section{WHICH SUBGROUP OF \\ MITRAL VALVE}

REPLACEMENT SHOULD BE COMPARED WITH MITRAL

VALVE REPAIR IN CONCOMITANT AORTIC AND MITRAL VALVE SURGERY?

\section{To the Editor:}

The article by Coutinho and colleagues ${ }^{1}$ draws attention to a classic topic that has not been deeply investigated, whether to replace or repair the mitral valve in double-valve surgery. We congratulate them for keeping our knowledge up to date on this issue. The efforts toward defining the exact solution have great importance. In this regard, we would like to make some contributions and discuss the subject.

It is a fact that although the reported freedoms from endocarditis $(P=$ $.002)$ and major valve-related adverse events $(P=.0026)$ were better for the mitral valve repair group, the expected concomitant improved survival ${ }^{1}$ was not seen. We think that the answer should be sought in the structural differences of the left ventricles when considering etiologic classification of both groups. The mitral valve repair group mainly consisted of patients with three etiologies (functional $[\mathrm{n}=$ $91 ; 43.5 \%]$, degenerative $[\mathrm{n}=44$; $21.1 \%]$, and rheumatic $[\mathrm{n}=58$; $27.8 \%$ ], whereas the mitral replacement group mainly consisted of patients with rheumatic etiology $(\mathrm{n}=40 ; 76.9 \%)$. When New York Heart Association functional classification was compared between the two groups, statistically significant differences were detected $(P=.015)$; however the pathophysiologic changes in the left ventricles resulting in New York Heart Association functional class III and IV were also different between the groups. It is well known that left ventricular function is well preserved in rheumatic mitral valve disease relative to degenerative or functional mitral valve disease. The primary pathologic condition in mitral valve stenosis is that the increased left atrial pressure is reflected on the pulmonary bed, whereas the primary pathologic condition in degenerative or functional mitral valve disease is decreased cardiac output, which is compensated for by left ventricular dilatation. Both mechanisms are responsible for the symptoms. This approach was confirmed by Coutinho and colleagues ${ }^{1}$ (left atrial diameter, 